\title{
Does brand orientation lead to brand loyalty among senior and top management in a South African business-to-business organisation?
}

\begin{tabular}{|c|c|}
\hline \multicolumn{2}{|c|}{$\begin{array}{l}\text { Authors: } \\
\text { Gail M. Dludla }{ }^{1} \\
\text { Siphiwe Dlamini }{ }^{2}\end{array}$} \\
\hline \multicolumn{2}{|c|}{$\begin{array}{l}\text { Affiliations: } \\
{ }^{1} \text { Wits Business School, } \\
\text { University of the } \\
\text { Witwatersrand, South Africa }\end{array}$} \\
\hline \multicolumn{2}{|c|}{$\begin{array}{l}{ }^{2} \text { School of Management } \\
\text { Studies, University of Cape } \\
\text { Town, South Africa }\end{array}$} \\
\hline \multicolumn{2}{|c|}{$\begin{array}{l}\text { Corresponding author: } \\
\text { Siphiwe Dlamini, } \\
\text { Siphiwe.dlamini@uct.ac.za }\end{array}$} \\
\hline \multicolumn{2}{|c|}{$\begin{array}{l}\text { Dates: } \\
\text { Received: } 14 \text { Mar. } 2017 \\
\text { Accepted: } 03 \text { Sept. } 2017 \\
\text { Published: } 03 \text { Oct. } 2018\end{array}$} \\
\hline \multicolumn{2}{|c|}{$\begin{array}{l}\text { How to cite this article: } \\
\text { Dludla, G.M. \& Dlamini, S., } \\
2018, \text { 'Does brand } \\
\text { orientation lead to brand } \\
\text { loyalty among senior and top } \\
\text { management in a South } \\
\text { African business-to-business } \\
\text { organisation?', South African } \\
\text { Journal of Business } \\
\text { Management } 49(1) \text {, a203. } \\
\text { https://doi.org/10.4102/ } \\
\text { sajbm.v49i1.203 }\end{array}$} \\
\hline \multicolumn{2}{|c|}{$\begin{array}{l}\text { Copyright: } \\
\text { (C) 2018. The Authors } \\
\text { Licensee: AOSIS. This } \\
\text { is licensed under the } \\
\text { Creative Commons } \\
\text { Attribution License. }\end{array}$} \\
\hline \multicolumn{2}{|l|}{ Read online: } \\
\hline ans: & $\begin{array}{l}\text { Scan this QR } \\
\text { code with your } \\
\text { smart phone or } \\
\text { mobile device } \\
\text { to read online. }\end{array}$ \\
\hline
\end{tabular}

Background: At the heart and depth of building a strong and prosperous brand in the marketplace, is brand orientation. A few studies have investigated the conceptualisation of brand orientation in relation to brand loyalty, as well as the involvement of brand commitment and brand trust in mediating this association in the business-to-business (B2B) environment.

Objective: It is the objective of this study to examine the impact of brand orientation on brand loyalty and the roles played by brand commitment and brand trust in mediating the impact in the South African B2B environment.

Method: Questionnaires were completed by 261 top and senior managers of a B2B organisation in South Africa. Structural equation modelling and smart partial least squares were employed in this study to examine the relationships between the constructs.

Results: This study provides empirical evidence that brand orientation has a positive and significant relationship with brand commitment and and brand trust. Also that brand commitment and brand trust have positive and significant relationships with brand loyalty in the South African B2B context.

Conclusion: This means that organisations that operate in the B2B environment should focus on brand orientation and develop brand strategies that recognise the importance of brand trust and brand commitment.

\section{Introduction}

From a projective branding paradigm perspective, brand orientation is an internalised organisation-based culture that takes into account the elements of branding in the organisation's overall business strategy (Osakwe, Chovancova \& Ogbonna 2016). Brand orientation has received much attention since its inception in the early 1990s by Frans Melin and Mats Urde (Gromark \& Melin 2013, Urde 1994; 1999). The key motives for the introduction of brand orientation were, firstly to develop a better understanding of a brand as a key strategic company resource as opposed to product enhancements and secondly, to extend knowledge on how to manage a brand successfully (Gromark \& Melin 2013). Central to a brand's market success and strength are the roles of an organisation's brand management capability and its brand orientation (Lee, O'Cass \& Sok 2017). However, Hirvonen, Laukkanen and Salo (2016) argue that organisations from outside the consumer realm have been highly sceptical about whether branding is important for them as well. This scepticism is apparent in the business-to-business (B2B) market environment. Consequently, brand orientation has been portrayed by many researchers as the core of the company strategy and resources (Gromark \& Melin 2013; King, So \& Grace 2013; Urde 1994, 1999; Urde, Baumgarth \& Merrilees 2013). Observing brands as strategic tools defies the market orientation model of regarding customer needs as the antecedents of brand development (Laukkanen et al. 2016). It is also understood as a more vigorous and holistic method than market orientation, assimilating both external and internal viewpoints on value creation (Gromark \& Melin 2013). Brand orientation epitomises an insideout tactic where the organisation's vision, mission and values direct brand development, setting restrictions to the degree to which organisations allow customer needs to impact branding decisions (Urde et al. 2013).

The theoretical manifestations of brand orientation have been argued by researchers such as Urde (1994); Simoes and Dibb (2001); and Baumgarth, Merrilees and Urde (2013). It has been discussed in relation to the concept of market orientation (Urde et al. 2013); brand equity 
(Baumgarth \& Schmidt 2010; Gromark \& Melin 2013; Zhang et al. 2016); integrated marketing communications (Reid, Luxton \& Mavondo 2005); and brand performance and brand identity in small companies (Hirvonen \& Laukkanen 2014; King et al. 2013). While branding is increasingly supported as a key indicator of performance and there has been a large body of research into branding in business-to-consumer (B2C) contexts, branding within the B2B marketing field has received inadequate academic attention, especially in the industrial services organisations (Zhang et al. 2016). For instance, there exists extensively recognised literature on brand orientation, where several authors adopt a customer behavioural perspective (Jones \& Rowley 2011; Schmidt et al. 2017). Evidently, few studies have explored the extent to which brand orientation influences employee behaviour. Even though several conceptual frameworks stress the importance of brand orientation management, empirical studies in this area are scarce. The current work extends previous research by empirically analysing the impact of brand orientation from the employees' perspective. The main aim of this study is thus to gain a better understanding of the brand orientation process from the employees' perspective and to investigate how the different dimensions of branding influence employees' behavioural responses. Particularly, it explores the effect of branding dimensions, such as brand commitment and brand trust, on senior and top management employees' organisational brand loyalty. In this context, few studies have been conducted on the mediating influence of brand commitment and brand trust in the relationship between brand orientation and brand loyalty. This effect is examined in relation to brand commitment and brand trust, in the context of a South African B2B organisation. The study will seek to address the following research questions:

- What is the impact of brand orientation on brand commitment?

- What is the impact of brand orientation on brand trust?

- What is the impact of brand commitment on brand loyalty?

- What is the impact of brand trust on brand loyalty?

The rest of the study proceeds as follows. The article begins with a literature review on brand orientation, brand commitment, brand trust and brand loyalty and develops hypotheses of the relationships between them. The following section discusses the research methodology and data collection process. Finally, the authors report and discuss the results and their implications, draw conclusions and propose directions for future research.

\section{Literature review: Brand orientation in the business-to-business environment}

Urde (1999) defines 'brand orientation' as:

an approach in which the processes of the organisation revolve around the creation, development and protection of brand identity in an ongoing interaction with target customers with the aim of achieving lasting competitive advantages in the form of brands. (p. 177)

Its definition was further enhanced by Gromark and Melin (2013) to be an intentional move towards brand building, whereby brand equity is produced through marketing communication, between internal and external stakeholders. With brand orientation, brand management is understood as core proficiency, and brand building is closely linked with corporate development and greater performance (Gromark \& Melin 2013). From a B2B perspective, brand orientation can be defined as an organisational behaviour that sets to engage and sustain a long-term relationship with employees.

Anees-ur-Rehman (2014) posits that the brand is a symbolic representation of an organisation and product values. Because the corporate brand name is a reflection of the values held by the organisation, industry buyers are also more sensitive to the organisation's brand image (Aneesur-Rehman 2014). The majority of the literature that has attempted to test the role of brands in a B2B environment is no more than 10 years old (Glynn 2012). Generally, these researchers have assessed the effect of brands on the buying process of the customer (Baumgarth \& Schmidt 2010). They have found that industrial supplier brands can generate customer loyalty, diminish risk, increase repeat purchase (Walley et al. 2007) and earn premium prices (Persson 2010). However, there is limited theoretical explanation for a brand strategy that is aligned with the characteristics of the B2B market (Glynn 2012; Leek \& Christodoulides 2012).

Hadjikhani and LaPlaca (2013) analyse B2B literature over the last 100 years and found that there is a conflict between two theoretical aspects: the economic and the behavioural theories. Economic theories view the marketing process as existing purely for financial profits, whereas behaviour theories take it a step further by accentuating more mutual benefits through developing strong relationships, specifically implemented behaviours and activities (Urde 1994). According to Anees-ur-Rehman (2014), the internal setting of that supplier should also exhibit the same behaviour and act according to the same brand values. The rationale for this is that suppliers should not be able to deliver the promised brand values to external customers if they are not generated internally (Burmann \& Zeplin 2005). Therefore, the theory of brand orientation purports that a strong brand is one that has maintained a strong relationship with internal and external stakeholders (Anees-ur-Rehman 2014; Hadjikhani \& La Placa 2013; Leek \& Christodoulides 2012). In light of the preceding discussion, this study uses the definition by Anees-urRehman (2014). Anees-ur-Rehman (2014) describes brand orientation in the B2B context as a strategic management method that utilises the value of the brand to cultivate relationships of a supplier with itself (internal stakeholders from top management to frontline staff) and external customers. 


\section{Conceptual model and hypothesis development}

\section{Brand orientation and brand commitment}

The establishment of brand commitment is an important element in strengthening internal brand management procedures and building a successful brand (Ahn, Hyun \& Kim 2016). 'Brand commitment' refers to an emotive attachment to a brand (Raju, Unnava \& Montgomery 2009). Du Preez and Bendixen (2015) find that research on brand commitment has often been outwardly focused, with very little attention paid to brand commitment internally. Brand orientation has to be based on relationships between partners that share the matching brand values and follow like strategies (Hankinson 2012). This is vital to the development of trust and commitment (Hirvonen \& Laukkanen 2014). As a central component of brand orientation, brand identity is said to be an antecedent of employee brand commitment (Burmann \& Zeplin 2005). In this study, 'brand commitment' refers to the degree of mental attachment of employees to the brand, which informs their willingness to put forth extra effort towards reaching the brand objectives (Hasnizam, Salniza \& Zokafli 2012). The brand orientation process affects employees' brand commitment; effective efforts with regard to internal branding give rise to employees' commitment towards the brand (Javanmard \& Nia 2011). Brand-oriented organisations attempt to encourage behavioural changes among employees so that they become committed (Chaudhuri \& Holbrook 2001). Based on the above discussion, the following hypothesis is investigated:

$\mathrm{H}_{1}$ : Brand orientation has an impact on brand commitment in the B2B context.

\section{Brand orientation and brand trust}

Yannopoulou et al. (2011) state that for trust to be noticeable, there have to be instances of high perceived risk. This is the foundation of the psycho-social model of trust conceptualised by Elliott and Yannopoulou (2007), where genuine trust in brands can only be created in circumstances of high perceived risk. Trust is seen as a vital component for the brand to forge a lasting relationship with individuals (Yannopoulou et al. 2011). Therefore, it is not surprising that different attributes, such as proficiency, goodwill and expertise, and human experiences, such as fulfilment, stimulate brand trust (Singh, Iglesias \& Batista-Foguet 2012). Research on the relationship between brand orientation and brand trust is limited. Organisations can develop emotional trust if they can demonstrate that the brand is there to meet expectations of fulfilling wants and needs (Chandio, Qureshi \& Ahmed 2015). In the B2B context, 'brand trust' is defined as the keenness of an employee to rely on the organisation's capability to perform its promised purpose (Chaudhuri \& Holbrook 2001). Organisations are able to positively influence the brand trust of consumers and also of prospective and current employees (Rampl \& Kenning 2014). Trust in organisations is different from trust between individuals, because the organisation also encompasses organisational standards and processes (Rampl \& Kenning 2014). Based on the literature reviewed above, it is evident that scholars have neglected the relationship between brand orientation and brand trust. Therefore, the study makes the following hypothesis:

$\mathrm{H}_{2}$ : Brand orientation has an impact on brand trust in the B2B context.

\section{Brand commitment and brand loyalty}

Behavioural loyalty guarantees that an individual's attitudinal loyalty can be translated into actual purchase behaviours - one of the key pointers utilised to measure the accomplishments of marketing strategies (Bianchi, Drennan \& Proud 2014). Among the first researchers to consider brand commitment as an antecedent of loyalty was Cunningham (1967). Developing attitudinal attachment is one of the most important approaches identified in building brand equity, and commitment is one of the considerations used for assessing brand equity (Cunningham 1967). The attitudinal perspective looks at the relationship between the individual and the brand, thus introducing the notion that loyalty cannot exist without commitment (Morgan \& Hunt 1994).

Studies referring to attitudinal loyalty view commitment as a way of distinguishing between genuine and fictitious loyalty (Mathew, Thomas \& Injodey 2012). Brand commitment thus represents the individual's wish to remain attached to and identify with the brand, and for this reason it is recognised as a key mediating tool in the construction of loyalty (Morgan \& Hunt 1994). Brand commitment is believed to be an antecedent of loyalty (Raïes \& Gavard-Perret 2011). 'Brand loyalty' is defined as the result from an individual's total disposition towards the brand (Chaudhuri \& Holbrook 2001). On this basis, the following hypothesis is examined:

$\mathrm{H}_{3}$ : Brand commitment has an impact on brand loyalty in the B2B context.

\section{Brand trust and brand loyalty}

Brand loyalty has been one of the most talked-about and most misconstrued marketing concepts for many years (Kabiraj \& Shanmugan 2011). Firstly, a loyal customer and a satisfied customer are not necessarily the same thing (Shih 2012). Customers may remain loyal for a number of reasons and may not even be happy with the product or service (Juntunen, Juntunen \& Juga 2011). A lack of customer defections does not necessarily indicate satisfied consumers (Kabiraj \& Shanmugan 2011). The cost of switching to an alternative supplier may be prohibitive or there may be a penalty clause. Switching suppliers may be inconvenient and the alternatives may not be attractive (Kabiraj \& Shanmugan 2011). Secondly, there are many reasons why a consumer may be loyal to a product, service or brand (Juntunen et al. 2011). Genuine satisfaction with the product or service is a key 
reason for remaining loyal (Kabiraj \& Shanmugan 2011). Understanding the drivers for brand loyalty is the first step to understanding how to influence them and thus increase profitability (Kabiraj \& Shanmugan 2011).

According to the studies on loyalty and trust, trust is one of the major antecedents of loyalty (Chaudhuri \& Holbrook 2001). Bianchi et al. (2014) argue that brand trust plays a mediating role in transforming the effects of the brand values into brand loyalty. Trust is a key driver of loyalty as it develops greatly valued trade relationships (Chandio et al. 2015). Brand loyalty is a vital product of the continuous process of furthering and sustaining a significant relationship, built on trust, between the brand and the individual (Chaudhuri \& Holbrook 2001). Thus, brand trust plays a very important role in developing and sustaining both attitudinal and behavioural aspects of brand loyalty (Bianchi et al. 2014). Brand loyalty is a result of brand trust or promises that build the highly valued connections (Chandio et al. 2015). Studies suggest that brand trust increases brand loyalty (Chaudhuri \& Holbrook 2001) and results in commitment, especially in B2B environments (Lee, Kim \& Chan-Olmsted 2011; Morgan \& Hunt 1994). Thus, the following hypothesis is investigated:

$\mathrm{H}_{4}$ : Brand trust has an impact on brand loyalty in the B2B context.

\section{Research methodology and data collection process}

Because the aim of the research study was to examine the relationship between brand orientation, brand commitment, brand trust and brand loyalty, the research strategy implemented was quantitative. The quantitative method is defined as a research method that seeks to quantify data and typically applies some form of statistical analysis (Malhotra \& Birks 2007). The population in the context of this study is the total number of 600 senior and top management-level employees in a South African Industrial Holdings organisation. The managerial emphasis on the brand orientation of a B2B organisation is on enabling and development of a strong organisational brand identity as the key for satisfying consumers. Similarly, Lee et al. (2017) sampled senior and middle-level managers, both related to the same brand. Both occupational levels were selected because they are the policymakers and decision-makers of the organisation, equally ensuring that employees understand the brand delivery standards. Using a Raosoft sample calculator the recommended sample was 235, which considers a 5\% margin of error and 95\% confidence level. Accordingly, we adopted a cluster random sampling technique by setting the sample size as 235, and therefore 600 senior and top management companies were contacted. The effective response rate was about $45 \%$, that is 261 of the 270 questionnaires returned were deemed to be appropriate and therefore used in the final data analysis.

\section{Research instrument}

The study took into consideration the measurement scales that were applied in previous studies as a guide to formulating the questionnaires that pertain to this study. The measurement scales for brand orientation were adapted from a study by Baumgarth and Schmidt (2010), the measurement scales for brand commitment were adapted from a study by Kimpakorn and Tocquer (2010), the measurement scales for brand trust were adapted from a study by Kimpakorn and Tocquer (2010) and the measurement scales for brand loyalty was adapted from a study by Chauhan and Mahajan (2013). All the constructs were reflective and were measured on a five-point Likert scale ranging from 1, 'strongly disagree', to 5 , 'strongly agree'.

\section{Data collection}

The hypotheses suggested in the proposed conceptual model (Figure 1) were tested using structural equation modelling (SEM) in SPSS 24 and smart partial least squares (PLS). Partial least squares-structural equation modelling has gained prominence as the next-level generation multivariate statistical technique for marketing research (Wong 2016). Given that the current study is exploratory research, we used the PLS-SEM approach to reveal the fundamental core of the study's hypothesised relationships. Osakwe et al. (2016) posit that PLS-SEM is a non-parametric approach that is very vigorous to multivariate non-normality, effective in working with a small sample size and notably valuable for making predictions, as this remains the core goal of this study. Structural equation modelling was suitable for this study as the sample size satisfies and meets both the guidelines as suggested by Hair et al. (2013) that a minimum of 59 respondents are needed to attain a statistical power of $80 \%$. It is for this reason that SEM performs better than other statistical techniques; it is problematic for scholars to model fundamental constructs that independent variables can load upon (Violato \& Hecker 2007). In the context of B2B, several studies have used SEM to estimate the measurement model and structural model with sample sizes varying from 142 to 258 (Cassia, Cobelli \& Ugolini 2017; Zhang et al. 2016). SEM is a valuable method for evaluating the succession of dependent variable relationships and confirming cause-andeffect relationships between various independent and dependent constructs. The demographic characteristics of the sample are presented in Table 1.

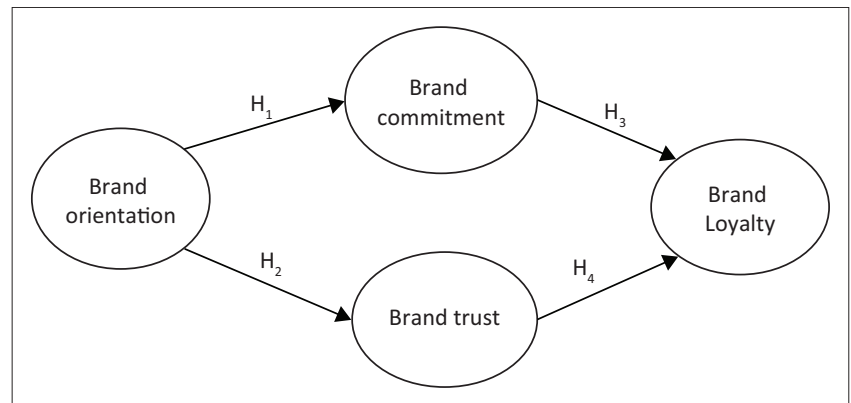

FIGURE 1: Conceptual research model. 
TABLE 1: Demographic characteristics of the sample.

\begin{tabular}{lc}
\hline Sample characteristics & Frequency (\%) \\
\hline Gender & 73.90 \\
Male & 26.10 \\
Female & \\
Race & 73.6 \\
White South Africans & 12.6 \\
Black South Africans & 4.2 \\
Mixed race & 9.6 \\
Indian & \\
Age & 11.5 \\
25-35 years & 27.2 \\
35-44 years & 23.8 \\
45-50 years & 37.5 \\
50 years and above & \\
Employment term & 8 \\
Less than 1 year & 18.8 \\
1-4 years & 21.1 \\
5-9 years & 11.9 \\
10-14 years & 40.2 \\
15 years and above & \\
Department & 18.4 \\
Finance & 3.1 \\
Human resources & 7.7 \\
Marketing & 4.2 \\
IT & 34.9 \\
Operations & 6.1 \\
Business development & 24.5 \\
Other & \\
\hline & \\
\hline & \\
\hline
\end{tabular}

IT, Information Technology.

\section{Ethical consideration}

No ethical clearance was applied for; however, organisational permission was obtained before conducting the study. The questionnaire had a consent form detailing the purpose of the study, anonymity and confidentiality, and involuntary participation. No identifiable information was required from the participants.

\section{Results}

The literature states that a higher level of Cronbach's alpha coefficient signifies a higher reliability of the measurement scale (Chinomona 2011). From the results illustrated in Table 2, the Cronbach's alpha value for the constructs ranges from 0.808 to 0.912 . All the alpha values exceed 0.6 , which is a benchmark recommended by Bernstein and Nunnally (1994). The composite reliability test was also carried out in order to study the internal reliability of each construct, as recommended by Chinomona (2011) and Nunnally, Bernstein and Berge (1967). A composite reliability index that is larger than 0.7 signifies sufficient internal consistency of a construct (Nunnally et al. 1967). In this study, the results of composite reliability, in Table 2, which range from 0.856 to 0.927, confirm the existence of internal reliability for all constructs in the study. All the average variance extracted (AVE) values exceed 0.50, ranging from 0.500 to 0.613 and therefore supporting convergent validity (Table 2). Generally, the results show great fit between constructs, as composite reliability values are above 0.80 , and AVE values for all latent constructs are greater than the threshold level of 0.50
(Fornell \& Larcker 1981). Incidentally, the final items utilised in the current study loaded well on their individual constructs with values ranging from 0.504 to 0.871 (see Table 3), with the exception of two measurement items, namely BL3 and BL6, whose values were below the 0.5 threshold. This thus signifies good convergent validity where items explain more than $50 \%$ of the underlying constructs. The item-to-total-correlation values are all above the recommended 0.5 benchmark. In fact, the item-to-totalcorrelation values range from 0.611 to 0.869 .

Proceeding from the discussion of discriminant validity, Hair et al. (2013) assert that when establishing whether or not there is discriminant validity, what must be done is to identify whether the observed variable displays a higher loading on its own construct than on any other construct included in the structural model. A way to ascertain the existence of discriminant validity is to examine if the correlation between the constructs is less than 1.0, as proposed by Chinomona (2011). As illustrated in Table 3, the intercorrelation values for all paired latent variables are less than 1.0, therefore confirming the existence of discriminant validity. In effect, the majority of the correlation coefficients, with the exception of brand commitment-brand loyalty (0.806), were less than 0.6. This is an indication of acceptable discriminant validity. The coefficient 0.806 can be deemed marginally acceptable.

\section{Assessment of the structural research model with tests of hypotheses}

As the second process in SEM (Chen et al. 2011), structural modelling was performed. In essence, the process is conducted for the purpose of assessing cause-and-effect relationships among latent variables (Nusair \& Hua 2010). This method comprises multiple regression analysis and path analysis and models the relationship between latent variables (Chen et al. 2011). Figure 2 is a depiction of the path model.

\section{Hypothesis testing results}

After evaluating and concluding the hypothesised measurement and structural model, the next action was to evaluate the cause-and-effect relationships among latent variables through path analysis (Nusair \& Hua 2010). Nusair and Hua (2010) observe that SEM states that specific latent variables directly or indirectly influence other specific latent variables with the model, causing estimation results that depict how these latent variables are associated. For this study, estimation results obtained through hypothesis testing are illustrated in Table 4 . The table demonstrates the proposed hypotheses, path coefficients, $t$-statistics and whether a hypothesis is rejected or supported. The literature suggests that $t>1.96$ is an indicator of relationship significance and that higher path coefficients indicate strong relationships among latent variables (Chinomona et al. 2010). Drawing from the results in Table $4, \mathrm{H}_{1}(t=9.482), \mathrm{H}_{2}(t=10.293)$, 
TABLE 2: Measurement accuracy statistics.

\begin{tabular}{|c|c|c|c|c|c|c|c|}
\hline \multirow[t]{2}{*}{ Research constructs } & \multicolumn{2}{|c|}{ Scale item } & \multicolumn{2}{|c|}{ Cronbach's test } & \multirow[t]{2}{*}{ CR } & \multirow[t]{2}{*}{ AVE } & \multirow[t]{2}{*}{ Factor loadings } \\
\hline & Mean & SD & Item - total & $\alpha$ value & & & \\
\hline \multicolumn{8}{|l|}{ Brand orientation } \\
\hline BO1 & 5.89 & 0.834 & 0.724 & 0.808 & 0.856 & 0.500 & 0.672 \\
\hline $\mathrm{BO} 2$ & 5.44 & 0.641 & 0.804 & - & - & - & 0.750 \\
\hline $\mathrm{BO} 3$ & 6.17 & 0.883 & 0.838 & - & - & - & 0.727 \\
\hline BO4 & 5.72 & 0.902 & 0.829 & - & - & - & 0.619 \\
\hline BO6 & 6.39 & 0.906 & 0.734 & - & - & - & 0.504 \\
\hline BO7 & 5.38 & 0.972 & 0.611 & - & - & - & 0.685 \\
\hline BO8 & 4.96 & 0.884 & 0.617 & - & - & - & 0.684 \\
\hline \multicolumn{8}{|l|}{ Brand commitment } \\
\hline BC1 & 6.30 & 0.775 & 0.634 & 0.852 & 0.888 & 0.536 & 0.824 \\
\hline BC2 & 6.53 & 0.980 & 0.657 & - & - & - & 0.820 \\
\hline BC3 & 5.92 & 0.798 & 0.770 & - & - & - & 0.837 \\
\hline BC6 & 6.28 & 0.822 & 0.613 & - & - & - & 0.561 \\
\hline BC7 & 4.87 & 0.752 & 0.677 & - & - & - & 0.617 \\
\hline BC8 & 6.34 & 0.667 & 0.701 & - & - & - & 0.698 \\
\hline \multicolumn{8}{|l|}{ Brand trust } \\
\hline BT1 & 4.95 & 0.880 & 0.818 & 0.889 & 0.915 & 0.613 & 0.507 \\
\hline BT2 & 6.16 & 0.669 & 0.840 & - & - & - & 0.758 \\
\hline BT3 & 6.02 & 0.977 & 0.869 & - & - & - & 0.711 \\
\hline BT4 & 5.66 & 0.921 & 0.759 & - & - & - & 0.838 \\
\hline BT5 & 5.74 & 0.735 & 0.723 & - & - & - & 0.881 \\
\hline BT6 & 5.53 & 0.833 & 0.715 & - & - & - & 0.858 \\
\hline BT7 & 5.66 & 0.780 & 0.677 & - & - & - & 0.860 \\
\hline \multicolumn{8}{|l|}{ Brand loyalty } \\
\hline BL1 & 5.98 & 0.883 & 0.702 & 0.912 & 0.927 & 0.564 & 0.649 \\
\hline BL2 & 5.94 & 0.690 & 0.626 & - & - & - & 0.735 \\
\hline BL7 & 6.20 & 0.867 & 0.657 & - & - & - & 0.743 \\
\hline BL8 & 420 & 0.978 & 0.620 & - & - & - & 0.871 \\
\hline BL9 & 6.26 & 0.728 & 0.639 & - & - & - & 0.682 \\
\hline BL10 & 6.22 & 0.995 & 0.782 & - & - & - & 0.601 \\
\hline BL11 & 6.51 & 0.981 & 0.654 & - & - & - & 0.738 \\
\hline BL12 & 6.04 & 0.782 & 0.701 & - & - & - & 0.861 \\
\hline
\end{tabular}

$\mathrm{CR}$, composite reliability; $\mathrm{AVE}$, average variance extracted; $\mathrm{SD}$, standard deviation; $\mathrm{BO}$, brand orientation; $\mathrm{BC}$, brand commitment; $\mathrm{BT}$, brand trust; $\mathrm{BL}$, brand loyalty.

TABLE 3: Correlation between the constructs.

\begin{tabular}{lcccc}
\hline Research constructs & BO & BC & BT & BL \\
\hline Brand orientation (BO) & 1.000 & - & - & - \\
Brand commitment (BC) & 0.546 & 1.000 & - & - \\
Brand trust (BT) & 0.607 & 0.575 & 1.000 & - \\
Brand loyalty (BL) & 0.513 & 0.806 & 0.547 & 1.000 \\
\hline
\end{tabular}

$\mathrm{H}_{3}(t=9.208)$ and $\mathrm{H}_{4}(t=7.882)$ are supported significantly because the $t$-statistics are greater than 1.96. Furthermore, all the posited hypotheses are positive, as expected, and are thus all accepted.

\section{Discussion}

The findings obtained from the test of $\mathrm{H}_{1}$ confirmed that there is a relationship between brand orientation and brand commitment. A path coefficient of 0.546 was realised after testing $\mathrm{H}_{1}$. This means that brand orientation has a strong influence on brand commitment - the second strongest relationship after the brand orientation-brand trust relationship. Furthermore, the results indicate that the relationship between brand orientation and brand commitment is positive and significant $(t=9.482)$. The findings are consistent with those of Burmann and Zeplin (2005) who conclude, in their study of the relationship between internal branding and brand commitment resulting in brand citizenship behaviour, that the three components of brand orientation (brand communication, brand leadership and brand-centred human resources-related activities) have a positive impact on brand commitment. The study also confirms findings of a study by Javanmard and Nia (2011) showing that brand orientation components have a positive effect on employees' brand commitment in the context of the Islamic banking sector. The results obtained from the test of $\mathrm{H}_{2}$ confirmed that there is a relationship between brand orientation and brand trust. A path coefficient of 0.609 was realised after testing $\mathrm{H}_{2}$. This means that brand orientation has a strong relationship with brand trust. This is the strongest relationship of all the posited hypotheses. Moreover, the results indicate that the relationship between brand orientation and brand trust is positive and significant $(t=10.293)$. In their study, Piehler, Hanisch and Burmann 


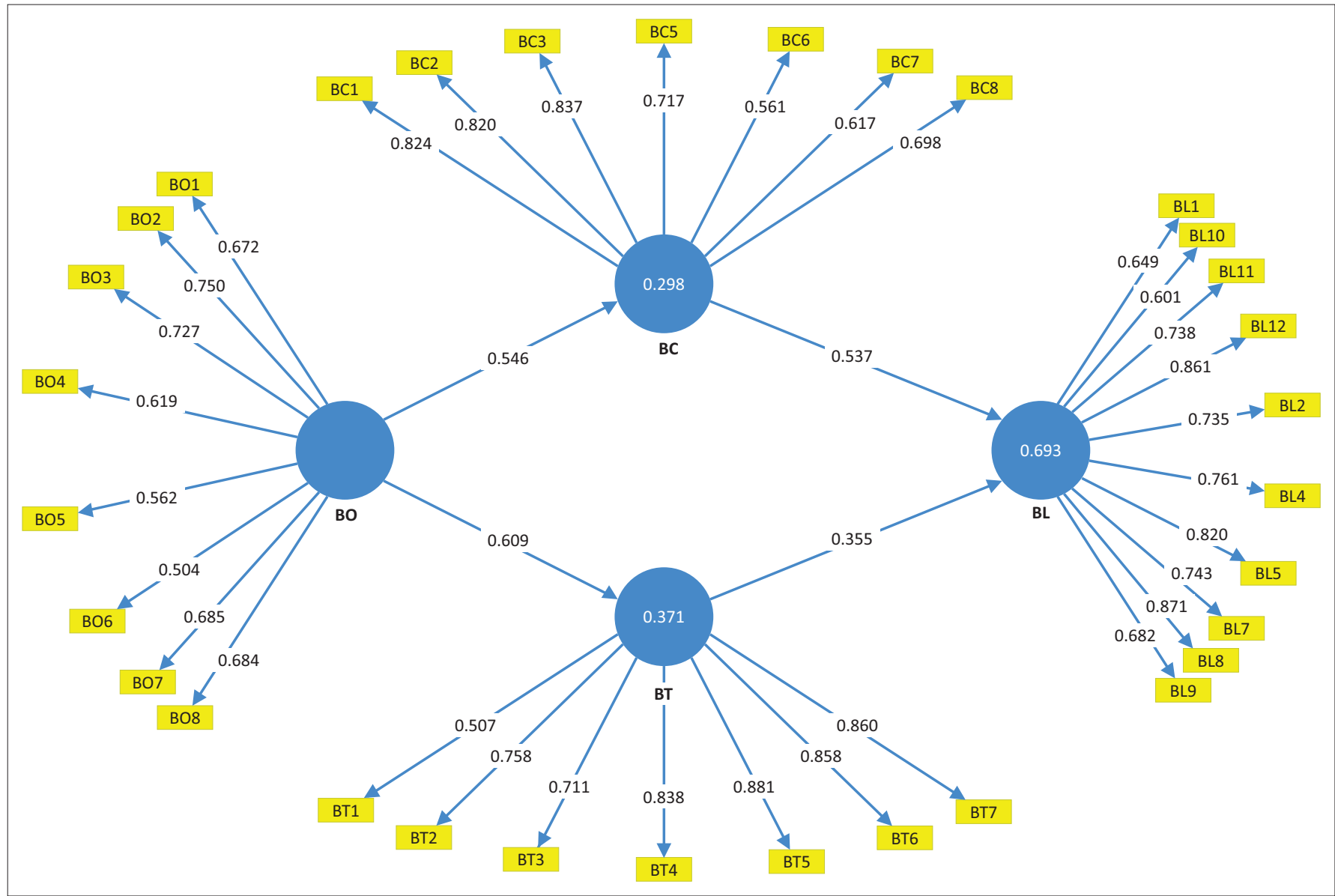

$\mathrm{BC}$, brand commitment; BL, brand loyalty; $\mathrm{BT}$, brand trust; $\mathrm{BO}$, brand orientation.

FIGURE 2: Path model. Similar to the CFA model, the circles symbolise the latent variables while the rectangles symbolise the observed variables. The unidirectional pointer signifies the impact of one variable on another.

TABLE 4: Hypothesis testing results.

\begin{tabular}{lccc}
\hline Proposed hypothesis relationship & Hypothesis & Path coefficient & Rejected or supported? \\
Brand orientation $\rightarrow$ brand commitment & $\mathrm{H}_{1}$ & 0.546 & 9.482 \\
Brand orientation $\rightarrow$ brand trust & $\mathrm{H}_{2}$ & 0.609 & 10.293 \\
Brand commitment $\rightarrow$ brand loyalty & $\mathrm{H}_{3}$ & 0.537 & Supported and significant \\
Brand trust $\rightarrow$ brand loyalty & $\mathrm{H}_{4}$ & 0.355 & 9.208 \\
\hline
\end{tabular}

Note: Arrows signify the relationships between each construct to indicate the proposed hypothesis.

(2015) found that dimensions of brand orientation are essential requirements for employee brand trust. Alhaddad (2015) also found that an element of brand orientation, brand image, has a significant and positive impact on brand trust. They further concluded that an additional manner for an organisation to strengthen brand trust is to be consistent and confident in all functions of the organisation. The results drawn from the test of $\mathrm{H}_{3}$ confirmed that there is a relationship between brand commitment and brand loyalty. A path coefficient of 0.537 was realised after testing $\mathrm{H}_{3}$. This means that brand commitment is significantly related to brand loyalty. It is the third strongest association when compared with the other proposed relationships. Moreover, the results indicate that the relationship between brand commitment and brand loyalty is positively related to brand loyalty in a significant way $(t=9.208)$. In their study, Raïes and GavardPerret (2011) revealed that an individual who is committed to the brand is more likely to spread positive word of mouth about it. This finding confirms the vital predictive role played by brand commitment regarding brand loyalty. The results of the study by Javanmard and Nia (2011) also confirm that employees' brand commitment has an effect on brand loyalty in the Islamic banking sector. Similarly, findings from the study by Mathew et al. (2012) revealed that brand commitment creates brand loyalty and this in turn adds to the growth of brand equity. The results obtained following the test of $\mathrm{H}_{4}$ confirmed that there is a relationship between brand trust and brand loyalty. A path coefficient of 0.355 was realised after testing $\mathrm{H}_{4}$. This means that brand trust has a stronger effect on brand loyalty - although it is the weakest of all the posited relationships. Furthermore, the results indicate that brand trust and brand loyalty are positively and significantly related $(t=7.882)$. The findings of the study by Setó-Pamies (2012) revealed that trust influences loyalty. The results of a study by Alhaddad (2015) showed that brand trust has a significant positive impact on brand loyalty. 


\section{Managerial and theoretical implications}

Tests were conducted in order to address the investigation of the impact of brand orientation on brand loyalty in relation to brand commitment and brand trust. It has emerged from the results of the study that brand orientation does indeed have an influence on both brand commitment and brand trust, which in turn also influence brand loyalty positively and significantly. However, brand orientation has a stronger influence on brand commitment than it does on brand trust; and brand trust has a stronger influence on brand loyalty than brand commitment.

This study contributes to the brand and brand management knowledge, particularly the brand orientation literature, by offering a conceptualisation of brand orientation as it relates to brand loyalty in a B2B context, as well as the mediating roles played by brand commitment and brand trust in facilitating this relationship. The study contributes to the current and existing literature on brand orientation, brand commitment, brand trust and brand loyalty. The study also contributes to the limited literature on the relationship between brand orientation and brand trust. The findings of the study reveal that, although there is a positive and significant relationship between the two constructs, the relationship between brand orientation and brand commitment proved to be even stronger. Furthermore, the relationship between brand trust and brand loyalty proved to be stronger than that between brand commitment and brand loyalty. This offers an opportunity for future research into the interplay of brand commitment and brand trust as mediators of the brand orientation-brand loyalty relationship. To reiterate the words of Gromark and Melin (2013), brand orientation captures an individual's passion for brands and becomes an organisation's form of expressing a desire to develop and communicate corporate identity. Companies ought to enforce brand orientation as a core strategy to ultimately get loyalty to their brand by instilling the principles and values of the brand into their employees. They need to encourage the employees to live the brand so that it becomes part of their lives. Employees have to witness the delivery of the brand promise.

\section{Limitations and future studies}

The current research has some limitations. Firstly, the current study has been restricted to testing the relationship between four variables only, namely brand orientation, brand commitment, brand trust and brand loyalty. Other researchers can use these constructs in other B2B sectors in emerging and developing markets. However, including other research constructs such as brand experience, brand satisfaction and brand advocacy might generate insightful findings. The study recommends that future research should utilise other constructs and generate an expanded conceptual model.
Additionally, future studies should consider comparing these results from South Africa with findings from other African or developing countries. If such a comparative study is conducted, it will provide practical insights into the influence of brand orientation on brand loyalty beyond South Africa's borders. Very limited literature exists on brand orientation and brand trust relationships. Although the study has made an attempt at increasing knowledge in this regard, it is recommended that further contributions be made towards enriching this literature. Although the current research and its theoretical supposition are supported by empirical evidence, future studies should attempt to investigate the underlying factors influencing particular causal relations and other outcomes not otherwise identified. In doing so, more knowledge with regard to antecedents of brand loyalty in the B2B sector will be uncovered, thus making a further contribution to existing literature on the subject.

The sample used in the study was limited to top and senior management. Future studies could expand the research sample to all occupation levels to include junior management, semi-skilled employees and unskilled employees. A quantitative research method was utilised for this study. Future studies could consider conducting qualitative research or mixed-methods research. The research design selected for the study was cross-sectional. Further studies could utilise research studies such as case studies, longitudinal or experimental designs.

\section{Acknowledgements}

The authors thank Bidvest for granting them permission to conduct this study among the senior and top managers of the organisation. They also thank the reviewers for their constructive feedback.

\section{Competing interests}

The authors declare that they have no financial or personal relationships which may have inappropriately influenced them in writing this article.

\section{Authors' contributions}

G.M.D. contributed to the write-up of the abstract, literature review, hypothesis development, methodology (including data collection), managerial and theoretical implications as well as limitations and future research. S.D. contributed to the overall development of the manuscript as prescribed by the journal guidelines, the introduction and model development, the data analysis, discussion of the results and completion of the reviewers' feedback.

\section{References}

Ahn, Y.J., Hyun, S.S. \& Kim, I., 2016, 'City residents' perception of MICE city brand orientation and their brand citizenship behavior: A case study of Busan, South Korea', Asia Pacific Journal of Tourism Research 21(3), 328-353. https://doi.org/1 0.1080/10941665.2015.1050422 
Alhaddad, A., 2015, 'A structural model of the relationships between brand image, brand trust and brand loyalty', International Journal of Management Research and Reviews 5(3), 137-144.

Anees-ur-Rehman, M., 2014, Clarifying the brand orientation construct for businessto-business sector, International Journal of Business and Management 9(12) $62-73$.

Baumgarth, C., Merrilees, B. \& Urde, M., 2013, 'Brand orientation: Past, present, and future', Journal of Marketing Management 29(9-10), 973-980. https://doi.org/1 $0.1080 / 0267257 X .2013 .817768$

Baumgarth, C. \& Schmidt, M., 2010, 'How strong is the business-to-business brand in the workforce? An empirically-tested model of 'internal brand equity' in a business-to-business setting', Industrial Marketing Management 39(8), 1250-1260. https://doi.org/10.1016/j.indmarman.2010.02.022

Bernstein, I.H. \& Nunnally, J., 1994, Psychometric theory, McGraw-Hill, New York.

Bianchi, C., Drennan, J. \& Proud, B., 2014, 'Antecedents of consumer brand loyalty in the Australian wine industry', Journal of Wine Research 25(2), 91-104. https:// doi.org/10.1080/09571264.2014.888650

Burmann, C. \& Zeplin, S., 2005, 'Building brand commitment: A behavioural approach to internal brand management', The Journal of Brand Management 12(4), 279300. https://doi.org/10.1057/palgrave.bm.2540223

Cassia, F., Cobelli, N. \& Ugolini, M., 2017, 'The effects of goods-related and servicerelated B2B brand images on customer loyalty', Journal of Business \& Industria Marketing 32(5), 722-732. https://doi.org/10.1108/JBIM-05-2016-0095

Chandio, Z.U., Qureshi, M.A. \& Ahmed, S., 2015, 'Brand trust, customer satisfaction and brand loyalty-A cross examination', Journal of Business Strategies 9(1), 62-81.

Chaudhuri, A. \& Holbrook, M.B., 2001, 'The chain of effects from brand trust and brand affect to brand performance: The role of brand loyalty', Journal of Marketing 65(2), 81-93. https://doi.org/10.1509/jmkg.65.2.81.18255

Chauhan, V. \& Mahajan, S., 2013, 'Employer branding and employee loyalty in hotel industry', International Journal of Hospitality and Tourism Systems 6(2), 34-43.

Chen, Y.Q., Zhang, Y.B., Liu, J.Y. \& Mo, P., 2011, 'Interrelationships among critical success factors of construction projects based on the structural equation model', Journal of Management in Engineering 28(3), 243-251. https://doi.org/10.1061/ (ASCE)ME.1943-5479.0000104

Chinomona, R., 2011, 'Non mediated channel powers and relationship quality: A case of SMES in Zimbabwe channels of distribution', PhD, National Central University, Taiwan.

Chinomona, R., Lin, J.Y.-C., Wang, M.C.-H. \& Cheng, J.M.-S., 2010, 'Soft power and desirable relationship outcomes: The case of Zimbabwean distribution channels', Journal of African Business 11(2), 182-200. https://doi.org/10.1080/15228916. Journal of Africd
2010.508997

Cunningham, S.M., 1967, 'Perceived risk and brand loyalty', Risk Taking and Information Handling in Consumer Behavior 1(1), 507-523.

Du Preez, R. \& Bendixen, M.T., 2015, 'The impact of internal brand management on employee job satisfaction, brand commitment and intention to stay, Internationa Journal of Bank Marketing 33(1), 78-91. https://doi.org/10.1108/IJBM-02-20140031

Elliott, R. \& Yannopoulou, N., 2007, The nature of trust in brands: A psychosocial model. European Journal of Marketing, 41(10), 988-998.

Fornell, C. \& Larcker, D.F., 1981, 'Evaluating structural equation models with unobservable variables and measurement error', Journal of Marketing Research 18(1), 39-50. https://doi.org/10.2307/3151312

Glynn, M.S., 2012, 'Primer in B2B brand-building strategies with a reader practicum' Journal of Business Research 65(5), 666-675. https://doi.org/10.1016/j. jbusres.2011.03.010

Gromark, J. \& Melin, F., 2013, 'From market orientation to brand orientation in the public sector', Journal of Marketing Management 29(9-10), 1099-1123. https:// doi.org/10.1080/0267257X.2013.812134

Hadjikhani, A. \& LaPlaca, P., 2013, 'Development of B2B marketing theory', Industrial Marketing Management 42(3), 294-305. https://doi.org/10.1016/j. indmarman.2013.03.011

Hair, J.F., Hult, G.T.M., Ringle, C. \& Sarstedt, M., 2013, A primer on partial least squares structural equation modeling (PLS-SEM), Sage, Thousand Oaks, CA.

Hankinson, G., 2012, 'The measurement of brand orientation, its performance impact, and the role of leadership in the context of destination branding: An exploratory study', Journal of Marketing Management 28(7-8), 974-999. https://doi.org/10. 1080/0267257X.2011.565727

Hasnizam, S., Salniza Md, S. \& Zolkafli, H., 2012, 'Relationship between brand knowledge and brand rewards, and employees' brand citizenship behavior: The mediating roles of brand commitment', International Journal of Business and Society 13(3), 335-354.

Hirvonen, S. \& Laukkanen, T., 2014, 'Brand orientation in small firms: An empirical test of the impact on brand performance', Journal of Strategic Marketing 22(1), 41-58. https://doi.org/10.1080/0965254X.2013.819372

Hirvonen, S., Laukkanen, T. \& Salo, J., 2016. Does brand orientation help B2B SMEs in gaining business growth?, Journal of Business \& Industrial Marketing 31(4), 472-487.

Javanmard, H. \& Nia, E.N., 2011, 'Effect of internal branding on brand supporting behaviors of employees regarding customer attraction in Islamic Banking', The IUP Journal of Brand Management 8(4), 35-46.

Jones, R. \& Rowley, J., 2011, 'Entrepreneurial marketing in small businesses: A conceptual exploration', International Small Business Journal 29(1), 25-36. https://doi.org/10.1177/0266242610369743
Juntunen, M., Juntunen, J. \& Juga, J., 2011, 'Corporate brand equity and loyalty in B2B markets: A study among logistics service purchasers', Journal of Brand Management 18(4/5), 300-311. https://doi.org/10.1057/bm.2010.43

Kabiraj, S. \& Shanmugan, J., 2011, 'Development of a conceptual framework for brand loyalty: A Euro-Mediterranean perspective', Journal of Brand Management 18(4/5), 285-299. https://doi.org/10.1057/bm.2010.42

Kimpakorn, N. \& Tocquer, G., 2010, 'Service brand equity and employee brand commitment', Journal of Services Marketing 24(5), 378-388. https://doi. org/10.1108/08876041011060486

King, C., So, K.K.F. \& Grace, D., 2013, 'The influence of service brand orientation on hotel employees' attitude and behaviors in China', International Journal of Hospitality Management 34(2), 172-180. https://doi.org/10.1016/j.ijhm.2013.03.004

Laukkanen, T., Tuominen, S., Reijonen, H. \& Hirvonen, S., 2016, 'Does market orientation pay off without brand orientation? A study of small business entrepreneurs', Journal of Marketing Management 32(7-8), 673-694. https:// doi.org/10.1080/0267257X.2015.1122659

Lee, C., Kim, J. \& Chan-Olmsted, S.M., 2011, 'Branded product information search on the Web: The role of brand trust and credibility of online information sources' Journal of Marketing Communications 17(5), 355-374. https://doi.org/10.1080/ 13527266.2010.484128

Lee, W.J., O'Cass, A. \& Sok, P., 2017, 'Unpacking brand management superiority: Examining the interplay of brand management capability, brand orientation and formalisation', European Journal of Marketing 51(1), 1-42. https://doi. org/10.1108/EJM-09-2015-0698

Leek, S. \& Christodoulides, G., 2011, 'A literature review and future agenda for B2B branding: Challenges of branding in a B2B context', Industrial Marketing Management 40(6), 830-837. https://doi.org/10.1016/j.indmarman.2011. 06.006

Leek, S. \& Christodoulides, G., 2012, 'A framework of brand value in B2B markets: The contributing role of functional and emotional components' Industrial Marketing Management 41(1), 106-114. https://doi.org/10.1016/j. indmarman.2011.11.009

Malhotra, N. \& Birks, D., 2007, Marketing research: An applied approach, Prentice Hall, London.

Mathew, V., Thomas, S. \& Injodey, J.I., 2012, 'Direct and indirect effect of brand credibility, brand commitment and loyalty intentions on brand equity', Economic Review: Journal of Economics \& Business / Ekonomska Revija: Casopis za Ekonomiju i Biznis 10(2), 73-82.

Morgan, R.M. \& Hunt, S.D., 1994, 'The commitment-trust theory of relationship marketing', The Journal of Marketing 58(3), 20-38. https://doi.org/10.2307/ 1252308

Nunnally, J.C., Bernstein, I.H. \& Berge, J.M.T., 1967, Psychometric theory, McGraw-Hill, New York.

Nusair, K. \& Hua, N., 2010, 'Comparative assessment of structural equation modeling and multiple regression research methodologies: E-commerce context', Tourism Management 31(3), 314-324. https://doi.org/10.1016/j.tourman.2009.03.010

Osakwe, C.N., Chovancova, M. \& Ogbonna, B.U., 2016, 'Linking SMEs profitability to brand orientation and market-sensing capability: A service sector evidence', Periodica Polytechnica, Social and Management Sciences 24(1), 34-40. https:// Periodica Polytechnica, Social
doi.org/10.3311/PPso.8069

Persson, N., 2010, 'An exploratory investigation of the elements of B2B brand image and its relationship to price premium', Industrial Marketing Management 39(8), 1269-1277. https://doi.org/10.1016/j.indmarman.2010.02.024

Piehler, R., Hanisch, S. \& Burmann, C., 2015, 'Internal branding-Relevance, management and challenges', Marketing Review St. Gallen 32(1), 52-61. https:// doi.org/10.1007/s11621-015-0506-8

Raïes, K. \& Gavard-Perret, M.L., 2011, 'Brand loyalty intention among members of a virtual brand community: The dual role of commitment', Recherche et Applications en Marketing (English Edition) (AFM c/o ESCP-EAP) 26(3), 23-41. https://doi.org/10.1177/205157071102600302

Raju, S., Unnava, H.R. \& Montgomery, N.V., 2009, 'The moderating effect of brand commitment on the evaluation of competitive brands', Journal of Advertising 38(2), 21-36. https://doi.org/10.2753/JOA0091-3367380202

Rampl, V.L. \& Kenning, P., 2014, 'Employer brand trust and affect: Linking brand personality to employer brand attractiveness', European Journal of Marketing 48(1/2), 218-236. https://doi.org/10.1108/EJM-02-2012-0113

Reid, M., Luxton, S. \& Mavondo, F., 2005, 'The relationship between integrated marketing communication, market orientation, and brand orientation', Journal of Advertising 34(4), 11-23. https://doi.org/10.1080/00913367.2005. 10639210

Schmidt, H.J., Mason, R., Steenkamp, P. \& Mugobo, V., 2017, 'Does brand orientation contribute to retailers' success? An empirical study in the South African market', Journal of Retailing and Consumer Services 38, 210-222. https://doi. org/10.1016/j.jretconser.2017.06.012

Setó-Pamies, D., 2012, 'Customer loyalty to service providers: Examining the role of service quality, customer satisfaction and trust', Total Quality Management \& Business Excellence 23(11/12), 1257-1271. https://doi.org/10.1080/14783363.2 012.669551

Shih, T.-Y., 2012, 'Integrative effects of firms' price and endorsement strategies on consumers' loyalty intention', Service Industries Journal 32(6), 981-1005. https:// doi.org/10.1080/02642069.2010.529133

Simoes, C. \& Dibb, S., 2001, 'Rethinking the brand concept: New brand orientation', Corporate Communications: An International Journal 6(4), 217-224. https://doi. org/10.1108/13563280110409854 
Singh, J., Iglesias, O. \& Batista-Foguet, J., 2012, 'Does having an ethical brand matter? The influence of consumer perceived ethicality on trust, affect and loyalty', Journal of Business Ethics 111(4), 541-549. https://doi.org/10.1007/s10551-012-1216-7

Urde, M., 1994, 'Brand orientation-a strategy for survival', Journal of Consumer Marketing 11(3), 18-32. https://doi.org/10.1108/07363769410065445

Urde, M., 1999, 'Brand orientation: A mindset for building brands into strategic resources', Journal of Marketing Management 15(1-3), 117-133. https://doi. org/10.1362/026725799784870504

Urde, M., Baumgarth, C. \& Merrilees, B., 2013, 'Brand orientation and marke orientation-From alternatives to synergy', Journal of Business Research 66(1) 13-20. https://doi.org/10.1016/j.jbusres.2011.07.018

Violato, C. \& Hecker, K.G., 2007, 'How to use structural equation modeling in medical education research: A brief guide', Teaching and Learning in Medicine 19(4), 362 371. https://doi.org/10.1080/10401330701542685
Walley, K., Custance, P., Taylor, S., Lindgreen, A. \& Hingley, M., 2007, 'The importance of brand in the industrial purchase decision: A case study of the UK tractor market', Journal of Business and Industrial Marketing 22(6), 383-393. https://doi. org/10.1108/08858620710780145

Wong, K. K. K. (2016). Mediation analysis, categorical moderation analysis, and higherorder constructs modeling in Partial Least Squares Structural Equation Modeling (PLS-SEM): A B2B Example using SmartPLS, Marketing Bulletin, 26, 1-22.

Yannopoulou, N., Koronis, E. \& Elliott, R., 2011, 'Media amplification of a brand crisis and its affect on brand trust', Journal of Marketing Management 27(5-6), 530546. https://doi.org/10.1080/0267257X.2010.498141

Zhang, J., Jiang, Y., Shabbir, R., Zhu, M., Johnston, W. \& Johnston, W., 2016, 'How brand orientation impacts B2B service brand equity? an empirical study among Chinese firms', Journal of Business \& Industrial Marketing 31(1), 83-98. https:// doi.org/10.1108/JBIM-02-2014-0041 